\title{
Characterization and process optimization of indigo dyed cotton denim garments by enzymatic wash
}

\author{
Md Ibrahim H Mondal ${ }^{*}$ and Md Mashiur Rahman Khan
}

\author{
* Correspondence: \\ mihmondal@yahoo.com \\ Polymer \& Textile Research Lab., \\ Department of Applied Chemistry \& \\ Chemical Engineering, Rajshahi \\ University, Rajshahi 6205, \\ Bangledesh
}

\begin{abstract}
Denim garment was treated with cellulase enzyme by varying the process parameters, namely concentration of enzyme, washing temperature and time to develop novel design and fashion. The effect of process parameters on the physical and mechanical properties of cotton denim garment was investigated and denim fabric properties like tensile strength, elongation at break, weight loss, stiffness, water absorption, shrinkage, color fading and morphological values by SEM were discussed. To obtain the desired fashion effect in terms of color fading, comfort ability in terms of reducing the stiffness of denim and high wear performance in terms of longevity/minimum tensile strength losses of denim, indigo dyed denim garment (trousers, 100\% cotton with twill weave 3/1 construction) had been chosen and processed with the enzyme concentration of $0.5 \%$ to $3.5 \%$, treatment temperature from $40^{\circ} \mathrm{C}$ to $70^{\circ} \mathrm{C}$ and treatment time from $20 \mathrm{~min}$ to $60 \mathrm{~min}$. The process parameters were optimized and the optimized washing condition for the best value is $2 \%$ enzyme concentration at $55^{\circ} \mathrm{C}$ for $40 \mathrm{~min}$.

Keywords: Denim; Cotton; Cellulase enzyme; Tensile strength
\end{abstract}

\section{Introduction}

Denim garment (Jeans) washing is one of the most widely used finishing treatments that have vast usage, due to its effects on appearance and comfort. Without washing, the denim garment is uncomfortable to wear, due to its weaving and dyeing effects. It essentially needs a finishing treatment to make it softer, more supple and smooth which enhance wearer's comfort. Popularity of garment washing especially of denim garment in the world market has been increasing day by day (Islam 2010). To keep up with the quickly changing of demands of customers, technologists are experimenting with new design and fashions by using different washing methods for denim garments. The most commonly used denim washing methods are enzyme wash, bleach wash, acid wash, normal wash, stone wash, etc. (Islam 2010; Kashem 2008). Among the washing methods, enzymatic methods are the most widely used method in industry (Buchert \& Heikinheimo 1998; Duran \& Mercela 2000; Kochavi et al. 1990; Tyndall 1990).

In this paper, the term novel design refers to eco-friendly sustainable apparel design which is the new challenge for apparel designers and producers, because the consumers are concerned in eco-fashion in the last decade. In the fast changing fashion

(C) 2014 Mondal and Khan; licensee Springer. This is an Open Access article distributed under the terms of the Creative Commons Attribution License (http://creativecommons.org/licenses/by/4.0), which permits unrestricted use, distribution, and reproduction in any medium, provided the original work is properly credited. 
trends, all are now motivated to practice sustainability in design and production throughout the textiles like the use of organic fibers and environmentally safe dyes and chemicals (Gam \& Banning 2011). In this regards, enzymatic treatment in denim garment washing is eco-friendly and effective for production sustainable denim garment. Again, consumers' environmental attitudes and apparel purchasing behavior has been increased now and their purchasing behavior is also influenced by the aesthetic attributes of the product (Butler \& Francis 1997; Eckman 1997). Therefore, enzymatic wash is very much effective to attract the customers, retailers, fashion marketers as well as denim apparel designers and producers.

Also, enzyme treatment has been used to improve softness as comfort, new look appearance as fashion and other surface characteristics of cotton denim garments by hydrolysis of cellulose molecules with cellulase (Kawamura \& Wakida 1989; Tyndall 1992; Walker \& Wilson 1991). Enzyme treatment of cellulosic garments degrades cellulose at the end or in the middle of the cellulose chains (Wood 1992), yielding shorter chain polymers and reducing its mechanical strength (Heikinheimo et al. 2000; Kang et al. 1998; Morries \& Harper 1994). However, cellulase treatments have been successful at improving fiber flexibility as comfort of cotton denim garments. For the above reasons, enzyme washing using cellulase is frequently chosen as a treatment process. Enzymes are bio-chemical substances which selectively work on substrate. The enzyme washing effect depends on the enzyme nature (acid/neutral enzyme).

Denim is a cotton and twill-weave fabric that uses colored warp and grey or white weft yarn and used for jeans, work clothes and casual wear. It is a very strong, stiff and hard wearing fabric (Razzaque 2004). It is normally dyed with indigo, vat and sulfur dyes. Indigo dyes are used for fashion dyeing; in denim, fibers dyed with indigo are not included in fiber-transfer examinations. The dye remains on surface (Grieve et al. 2006; Grieve \& Biermann 1997.

Again, bleach method also have been widely used for denim washing. But bleach is a harsh chemical, harmful to human health, causes corrosion to washing machine and destructive to cotton. It may cause damage to cellulose in severe strength losses (Islam 2010). Recently, the use of hypochlorite in denim washing has been discouraged due to chlorine liberation and it is harmful to environment (Prabaharan et al. 2000).

Many researchers have investigated the washing of denim garments using various methods but there is a lack of research on the process optimization of denim garment washing to develop new look designs as fashion with maximum longevity as high wear performance by an enzymatic method. The present investigation is focused on process optimization considering developing new look/fashion, enhancing softness/wearer's comfort and longevity/high wear performance of the garment with minimum losses in tensile strength. In addition, the effects of various process parameters using cellulase was investigated and discussed.

\section{Materials and methods}

Materials

Indigo dyed denim fabric was collected from a textile mill and then manufactured denim garments (trousers) in a sewing laboratory. The fabric comprised $100 \%$ cotton, GSM 318 (Per square meter fabric weight is 318 gram), twill weave (3/1), construction: 70 (Ends/inch) X 42 (Picks/inch) / 10 Ne (Warp yarn count) X 9 Ne (Weft yarn count). 
Denim garments were desized using the standard recipe and processed with cellulase. After that processed with cationic softener and characterized.

Genzyme SL (a cellulase enzyme, Sri Lanka); Jet (an anionic detergent, Bangladesh); Bio.D. (a desizing agent, Germany); soda ash (China), acetic acid (China) and Textsoft (a cationic softener, Germany) were used as reagent grade.

\section{Methods}

Desizing

The desizing was conducted in liquor containing soda ash $(1.2 \mathrm{~g} / \mathrm{l})$, detergent $(0.6 \mathrm{~g} / \mathrm{l})$, and desizing agent $(0.6 \mathrm{~g} / \mathrm{l})$ and material to liquor ratio of 1:30 in an industrial horizontal sample washing machine (Ngai Shing, model-NS 2205, Hong Kong) at temperature $60^{\circ} \mathrm{C}$ for $20 \mathrm{~min}$. After that washed with hot water $\left(70^{\circ} \mathrm{C}\right)$ followed by cold water $\left(40^{\circ} \mathrm{C}\right)$ wash.

\section{Enzyme (cellulase) treatment}

The process was conducted in liquor containing acetic acid (1.0 g/l) at pH 5.5 and material to liquor ratio of 1:30 with cellulase in the washing machine. The process was carried out at different concentration of Genzyme SL (0.5\% - 3.5\%), temperature of $\left(40^{\circ} \mathrm{C}-70^{\circ} \mathrm{C}\right)$ and treatment time $(20 \mathrm{~min}-60 \mathrm{~min})$. After desired time the temperature was raised to $90^{\circ} \mathrm{C}$ for $1 \mathrm{~min}$ to stop enzymatic action then washed with hot distilled water followed by cold $\left(40^{\circ} \mathrm{C}\right)$ distilled water. Finally, garments were processed with Textsoft $(1.0 \mathrm{~g} / \mathrm{l})$ at $40^{\circ} \mathrm{C}$ for $10 \mathrm{~min}$.

\section{Hydro-extracting and drying Processes}

Processed denim trousers were squeezed in a laboratory scale hydro-extractor machine (Roaches, England) at $200 \mathrm{rpm}$ for $4 \mathrm{~min}$ and dried in a steam drier (Opti-Dry, England) at $75^{\circ} \mathrm{C}$ for $40 \mathrm{~min}$.

\section{Testing and analysis}

To obtain product performance cellulase treated denim garments were tested using a tensile strength tester (Goodman, England), stiffness tester (Shirley, England), gray scale (AATCC 61) to color fading, fabric construction and scanning electron micrograph (Hitachi, Japan). Before testing samples were conditioned in testing laboratory at $65 \%$ relative humidity and at $20^{\circ} \mathrm{C}$ for 24 hour (ASTM D 1776 2008).

Color shade of the fabric was rated using gray scale for color change according to AATCC test method 61 (2010). Tensile strength and elongation at break was determined using fabric strength tester according to ASTM D 5034 (2009). Stiffness was measured using the bending stiffness in fabric using stiffness tester according to BS 3356 (1990). Dimensional changes (shrinkage\%) was calculated from the difference in fabric length before and after treatment according to AATCC test method 96 (2009). Weight loss (\%) in fabric was calculated from the difference in fabric weight (GSM) before and after the treatment according to ASTM D 3776 (1996). Moisture regains and moisture content (\%) was calculated from the difference in total fabric weight and oven dry weight according to ASTM D 1909 (2004). Water absorption (rate of uptake) was measured according to BS 3449 (1990). Morphological value was studied using a scanning electron microscopy (SEM). 


\section{Results and discussion}

\section{Effect of cellulase enzyme concentrations on denim garment washing}

The physical and mechanical properties of denim garments treated at different cellulase concentrations were measured and the results are summarized in Table 1 . It can be seen from Table 1 that, treatment of denim garments with cellulase at $0.5 \%$ concentration caused significantly decrease in tensile strength and this decrease was higher at higher cellulase concentrations up to $3.5 \%$. During washing, cellulase hydrolyzed cotton. First, it attacked on projecting fibers (micro-fibrils) on surface, then attacked on yarn portion, hydrolyzed them slowly and upon time penetrated inside the fabric. The result of this reaction is that the primary wall (outer layer) of the cotton fiber is loosened and broken down quicker with the frictional action (mechanical forces) of rotating cylinder of the washing machine. This effect also depends on the washing conditions. Hydrolysis of cellulose would certainly affect fabric properties, namely, tensile strength, stiffness, elongation at break, water absorption, moisture regain, moisture content and fabric surface characteristics. Similar results for tensile strength have previously been obtained with undyed cotton cellulose (Heikinheimo et al. 1998; Kleman-Leyer et al. 1996). From, Table 1 it can be seen that at 3\% cellulase concentration the strength loss is higher. By considering all the properties of treated denim it can be seen from Table 1 that $2 \%$ cellulase concentration is the optimum result for denim garment washing.

Denim hydrolysis was measured by monitoring the color fading from treated garments (Table 1). It can be seen from the Table 1 that the color shade of denim garments decreased significantly after they were exposed to cellulase treatment particularly at higher concentrations of $2.0 \%$ to $3.0 \%$. During washing, the part of the primary wall of cotton is always in contact with cellulase, so at the contact point, fiber surfaces are hydrolyzed by the catalysis of the cellulase and then treated garments become duller and color is faded. The hair-like cotton fibrils are degraded first and partly detached from the main fiber chain and indigo dye bonds are broken from the yarn surface. Rotating garments inside washing machine hydrolyzes more bonds due to mechanical friction, restores their original white color. The results disclose that increasing the cellulase concentration from 3.0 to $3.5 \%$ has no effect on color shade change, because with $3.0 \%$ cellulase concentration most of the indigo dyes are loosened from the fabric surface and no dyes are remain on fabric surface. Therefore no effect found on color shade change when increased cellulase concentration 3.0 to $3.5 \%$. From Table 1 it can also be seen that $2 \%$ cellulase concentration is the optimum result for color fading.

Denim hydrolysis by measuring the stiffness of denim garments was also monitored. The stiffness of the denim garments decreased at $0.5 \%$ cellulase concentration, and the decrease was more pronounced at higher cellulase concentrations up to 3.0\%. After treatment with cellulase, the starch of warp yarns was removed. As a result, bending length was less and stiffness was decreased in comparison to untreated. The decrease bending length was more pronounced at higher cellulase concentrations up to $3 \%$, and stiffness was decreased to $44.6 \%$ of the original garment. At $2 \%$ cellulase concentration the stiffness decreased to $41.8 \%$ which is the closest to desired level. Water absorption rate of denim garment was $155 \%$, whereas unwashed denim was $126 \%$ absorption (Table 1).

Moisture content is a measure of the level of water in the denim samples. It can also be seen from Table 1 that the moisture content of the treated samples are similar and in the range of $8.81-8.93 \%$, whereas untreated sample was $7.4 \%$. The same holds also 
Table 1 Effect of cellulase enzyme concentration on the physical and mechanical properties of treated denim garments

\begin{tabular}{|c|c|c|c|c|c|c|c|c|c|c|c|}
\hline \multirow{2}{*}{$\begin{array}{l}\text { Conc. of cellulase } \\
\text { enzyme } \% \text { (owf) }\end{array}$} & \multicolumn{2}{|c|}{ Tensile strength (Kg f) } & \multirow{2}{*}{$\begin{array}{l}\text { Dimensional stability } \\
\text { (shrinkage, \%) }\end{array}$} & \multirow{2}{*}{$\begin{array}{l}\text { Weight of } \\
\text { fabric (GSM) }\end{array}$} & \multirow[t]{2}{*}{ Stiffness (cm) } & \multirow{2}{*}{$\begin{array}{l}\text { Water } \\
\text { absorption (\%) }\end{array}$} & \multirow{2}{*}{$\begin{array}{l}\text { Moisture } \\
\text { content (\%) }\end{array}$} & \multirow{2}{*}{$\begin{array}{l}\text { Moisture } \\
\text { regain (\%) }\end{array}$} & \multirow[t]{2}{*}{ EPI \& PPI } & \multirow{2}{*}{$\begin{array}{l}\text { Elongation } \\
\text { at break (\%) }\end{array}$} & \multirow{2}{*}{$\begin{array}{l}\text { Color shade } \\
\text { (rating) }\end{array}$} \\
\hline & Warp & Weft & & & & & & & & & \\
\hline 0.0 Before wash & $245(0)$ & $136(0)$ & 0 & $318(0)$ & $4.5(0)$ & 126 & 7.40 & 7.53 & $70 \times 42$ & $L=21 W=16$ & 5 \\
\hline 0.5 & $230(-6 \%)$ & $124(-9 \%)$ & $L=-4.75 W=0$ & $326(+2.5 \%)$ & $3.2(-28 \%)$ & 145 & 8.81 & 7.95 & $70 \times 46$ & $L=36 W=20$ & $4 / 5$ \\
\hline 1.0 & $220(-10 \%)$ & $120(-12 \%)$ & $L=-5.6 \mathrm{~W}=+0.5$ & $328(+3.0 \%)$ & $3.1(-31 \%)$ & 150 & 8.90 & 8.20 & $70 \times 46$ & $L=37 W=22$ & 4 \\
\hline 2.0 & $205(-16 \%)$ & $106(-22 \%)$ & $L=-6.4 W=+0.5$ & $334(+5.0 \%)$ & $2.62(-41.8 \%)$ & 155 & 8.92 & 8.60 & $69 \times 46$ & $L=37 W=22$ & $3 / 4$ \\
\hline 3.0 & $190(-22 \%)$ & $97(-29 \%)$ & $L=-6.3 W=+1.0$ & $334(+5.0 \%)$ & $2.49(-44.6)$ & 156 & 8.93 & 8.60 & $69 \times 46$ & $L=34 W=20$ & 3 \\
\hline 3.5 & $190(-22 \%)$ & $91(-33 \%)$ & $L=-6.3 W=+1.0$ & $330(+3.7 \%)$ & $2.49(-44.6 \%)$ & 156 & 8.93 & 8.60 & $69 \times 46$ & $L=34 W=20$ & 3 \\
\hline
\end{tabular}

A value at 0.0 concentrations represents the denim garments without cellulase enzyme treatment.

Conditions used for enzyme washing treatment: cellulase enzyme, 0.5-3.5\%; acetic acid, $1 \mathrm{~g} /$; temperature, $55^{\circ} \mathrm{C} ;$ time, $40 \mathrm{~min} ; \mathrm{pH}, 5.5 ; \mathrm{M:L} \mathrm{L}, 1: 30$. 
true for elongation at break. Elongation at break of the treated denim garments are very close to similar and lengthwise denim elongation was $34-37 \%$ and widthwise denim elongation was $20-22 \%$, whereas lengthwise elongation of untreated denim was $21 \%$ and widthwise elongation was $16 \%$ respectively.

It can also be seen from Table 1 that cellulase treatment by washing of the denim garments with cellulase at $0.5 \%$ concentration caused increase in GSM (fabric weight) of the garments, whereas weight loss (GSM decreased) results have previously been obtained with direct and reactive dyed cotton fabric substrate. During weaving, cotton fabrics are subjected to considerable tensions, particularly in the warp direction. In subsequent finishing processes, such as calendaring this stretch is increased and temporarily set in the fabric. The fabric is then in a state of dimensional instability (Cookson 1992). Subsequently when the denim garment was thoroughly wetted in enzyme washing, it tended to revert its more stable dimensions which results in the contraction of the yarns. This effect is usually greater in the warp direction than in the weft direction. This is known as relaxation shrinkage. Due to relaxation shrinkage, PPI (picks per inch) is higher in treated, compared to untreated denim garments. As a result, fabric GSM is increased at different cellulase concentrations and $2 \%$ cellulase concentration is optimum result (Table 1). Although hydrolysis occurred in cellulase washing, at the same time relaxation shrinkage occurred, and the GSM (fabric weight) of denim garments increased slightly. But the use of higher concentrations of cellulase (3.5\%) brought losses in fabric weight due to more hydrolysis of cellulose. It was observed that $2 \%$ concentration of cellulase results in the maximum increase in fabric weight, compared to the other concentrations.

Thus, $2 \%$ cellulase is optimal because this concentration of cellulase exhibited the maximum decrease in fabric stiffness and shrinkage; and maximum increase in water absorption, elongation at break and GSM as compared with the other concentrations.

\section{Effect of temperature in cellulase enzyme washing on denim garment}

The effects of $2 \%$ cellulase in denim washing under the influence of $40^{\circ} \mathrm{C}, 45^{\circ} \mathrm{C}, 50^{\circ} \mathrm{C}$, $55^{\circ} \mathrm{C}, 60^{\circ} \mathrm{C}$ and $70^{\circ} \mathrm{C}$ for $40 \mathrm{~min}$ was investigated. The effects of temperature on tensile strength, stiffness, color fading, fabric weight, elongation at break, water absorption, moisture regain, moisture content and shrinkage of denim garments are shown in Table 2. The results show that raising the temperature from 40 to $65^{\circ} \mathrm{C}$ has an effect on tensile strength, stiffness and color fading. At 60 and $65^{\circ} \mathrm{C}$, the color shade decreased, and a higher temperature $\left(70^{\circ} \mathrm{C}\right)$ does not cause any further decrease in color shade, because the action of cellulase is lowest at higher temperature. The effect of temperature on stiffness and water absorption is clear particularly when washing was performed at $50^{\circ} \mathrm{C}$ and $60^{\circ} \mathrm{C}$, because of the loosening of surface fibers caused by washing temperature. GSM was lower at $65^{\circ} \mathrm{C}$ and $70^{\circ} \mathrm{C}$ but substantially higher GSM values were obtained at $55^{\circ} \mathrm{C}$. The effect of temperature on color fading and surface roughness is clear particularly when cellulase was performed at $55^{\circ} \mathrm{C}$.

\section{Effect of time in cellulase enzyme washing on denim garment}

The effects of $2 \%$ cellulase in denim washing at $55^{\circ} \mathrm{C}$ for $20,30,40,45,50,55$ and 60 min were investigated. The effect of time on tensile strength, stiffness, color fading, fabric weight, elongation at break, water absorption, moisture regain, moisture content 
Table 2 Effect of temperature on the physical and mechanical properties of treated denim garments

\begin{tabular}{|c|c|c|c|c|c|c|c|c|c|c|c|}
\hline \multirow[t]{2}{*}{ Temp. $\left({ }^{\circ} \mathrm{C}\right)$} & \multicolumn{2}{|c|}{ Tensile strength $(\mathrm{Kg} \mathbf{f})$} & \multirow{2}{*}{$\begin{array}{l}\text { Dimensional stability } \\
\text { (shrinkage \%) }\end{array}$} & \multirow{2}{*}{$\begin{array}{l}\text { Weight of } \\
\text { fabric (GSM) }\end{array}$} & \multirow[t]{2}{*}{ Stiffness $(\mathrm{cm})$} & \multirow{2}{*}{$\begin{array}{l}\text { Water } \\
\text { absorption (\%) }\end{array}$} & \multirow{2}{*}{$\begin{array}{l}\text { Moisture } \\
\text { content (\%) }\end{array}$} & \multirow{2}{*}{$\begin{array}{l}\text { Moisture } \\
\text { regain (\%) }\end{array}$} & \multirow[t]{2}{*}{ EPI \& PPI } & \multirow{2}{*}{$\begin{array}{l}\text { Elongation } \\
\text { at break (\%) }\end{array}$} & \multirow{2}{*}{$\begin{array}{l}\text { Color } \\
\text { shade }\end{array}$} \\
\hline & Warp & Weft & & & & & & & & & \\
\hline 0.0 Before wash & $245(0)$ & $136(0)$ & $0(0)$ & $318(0)$ & $4.5(0)$ & 126 & 7.4 & 7.53 & $70 \times 42$ & $L=21 W=16$ & 5 \\
\hline 40 & $223(-9 \%)$ & $118(-13 \%)$ & $L=-6.0 W=0$ & $330(+3.8 \%)$ & $3.0(-33 \%)$ & 145 & 8.81 & 7.95 & $70 \times 46$ & $L=36 W=20$ & $4 / 5$ \\
\hline 50 & $213(-13 \%)$ & $110(-19 \%)$ & $L=-6.2 W=0$ & $334(+5.0 \%)$ & $2.78(-38 \%)$ & 150 & 8.90 & 8.20 & $70 \times 46$ & $L=37 W=22$ & \\
\hline 55 & $205(-16 \%)$ & $106(-22 \%)$ & $L=-6.4 W=+0.5$ & $334(+5.0 \%)$ & $2.62(-41.8 \%)$ & 155 & 8.92 & 8.60 & $69 \times 46$ & $L=37 W=22$ & $3 / 4$ \\
\hline 60 & $193(-21 \%)$ & $95(-30 \%)$ & $L=-6.6 \mathrm{~W}=+1.0$ & $334(+5.0 \%)$ & $2.50(-44.4 \%)$ & 158 & 8.94 & 8.60 & $69 \times 46$ & $L=33 W=24$ & 3 \\
\hline 65 & $190(-22 \%)$ & $95(-30 \%)$ & $L=-7.2 W=+1.0$ & $333(+4.7 \%)$ & $2.48(-44.8 \%)$ & 158 & 8.93 & 8.60 & $69 \times 46$ & $L=33 W=24$ & $2 / 3$ \\
\hline 70 & $190(-22 \%)$ & $95(-30 \%)$ & $L=-7.2 W=+1.0$ & $332(+4.4 \%)$ & $2.47(-45.1 \%)$ & 158 & 8.95 & 8.60 & $69 \times 46$ & $L=33 W=24$ & $2 / 3$ \\
\hline
\end{tabular}

Values at 0.0 concentrations represent the denim garments without cellulase enzyme treatment.

Conditions used: cellulase enzyme, $2 \%$; acetic acid, $1 \mathrm{~g} /$; temperature, $40-70^{\circ} \mathrm{C} ;$ time, $40 \mathrm{~min} ; \mathrm{pH}, 5.5 ; \mathrm{M}: \mathrm{L}, 1: 30$. 
Table 3 Effect of time on the physical and mechanical properties of treated denim garments

\begin{tabular}{|c|c|c|c|c|c|c|c|c|c|c|c|}
\hline \multirow[t]{2}{*}{ Time (min) } & \multicolumn{2}{|c|}{ Tensile strength (Kg f) } & \multirow{2}{*}{$\begin{array}{l}\text { Dimensional stability } \\
\text { (shrinkage\%) }\end{array}$} & \multirow{2}{*}{$\begin{array}{l}\text { Weight of } \\
\text { fabric (GSM) }\end{array}$} & \multirow[t]{2}{*}{ Stiffness(cm) } & \multirow{2}{*}{$\begin{array}{l}\text { Water } \\
\text { absorption (\%) }\end{array}$} & \multirow{2}{*}{$\begin{array}{l}\text { Moisture } \\
\text { content (\%) }\end{array}$} & \multirow{2}{*}{$\begin{array}{l}\text { Moisture } \\
\text { regain (\%) }\end{array}$} & \multirow[t]{2}{*}{ EPI \& PPI } & \multirow{2}{*}{$\begin{array}{l}\text { Elongation } \\
\text { at break (\%) }\end{array}$} & \multirow{2}{*}{$\begin{array}{l}\text { Color shade } \\
\text { (rating) }\end{array}$} \\
\hline & Warp & Weft & & & & & & & & & \\
\hline 0.0 Before wash & $245(0)$ & $136(0)$ & 0 & $318(0)$ & $4.5(0)$ & 126 & 7.4 & 7.53 & $70 \times 42$ & $L=21 W=16$ & 5 \\
\hline 20 & $223(-9 \%)$ & $118(-13 \%)$ & $L=-6.0 W=0$ & $330(+3.8 \%)$ & $3.0(-33 \%)$ & 145 & 8.81 & 7.95 & $70 \times 46$ & $L=36 W=20$ & 4 \\
\hline 30 & $213(-13 \%)$ & $110(-19 \%)$ & $L=-6.2 W=0$ & $334(+5.0 \%)$ & $2.78(-38 \%)$ & 150 & 8.90 & 8.20 & $70 \times 46$ & $L=37 W=22$ & 4 \\
\hline 40 & $205(-16 \%)$ & $106(-22 \%)$ & $L=-6.4 W=+0.5$ & $334(+5.0 \%)$ & $2.62(-41.8 \%)$ & 155 & 8.92 & 8.60 & $69 \times 46$ & $L=37 W=22$ & $3 / 4$ \\
\hline 45 & $201(-18 \%)$ & $101(-26 \%)$ & $L=-6.4 W=+0.5$ & $335(+5.3 \%)$ & $2.60(-42.2 \%)$ & 156 & 8.93 & 8.60 & $69 \times 46$ & $L=34 W=20$ & $3 / 4$ \\
\hline 50 & $195(-20 \%)$ & $98(-28 \%)$ & $L=-6.3 W=+1.0$ & $336(+5.6 \%)$ & $2.52(-44 \%)$ & 156 & 8.95 & 8.60 & $69 \times 46$ & $L=34 W=24$ & $3 / 4$ \\
\hline 55 & $190(-22 \%)$ & $95(-30 \%)$ & $L=-7.2 W=+1.0$ & $333(+4.7 \%)$ & $2.48(-44.8 \%)$ & 158 & 8.93 & 8.60 & $69 \times 46$ & $L=33 W=24$ & 3 \\
\hline 60 & $190(-22 \%)$ & $95(-30 \%)$ & $L=-7.2 W=+1.0$ & $332(+4.4 \%)$ & $2.47(-45.1 \%)$ & 158 & 8.95 & 8.60 & $69 \times 46$ & $L=33 W=24$ & 3 \\
\hline
\end{tabular}

Values at 0.0 concentrations represent the denim garments without cellulase enzyme treatment.

Conditions used for enzyme washing treatment: cellulase enzyme, 2\%; acetic acid, $1 \mathrm{~g} / /$; temperature, 55 $55^{\circ} \mathrm{C}$ time, $20 \mathrm{~min}-60 \mathrm{~min} ; \mathrm{pH}, 5.5 ; \mathrm{M}: \mathrm{L}, 1: 30$. 
and shrinkage is shown in Table 3. The results indicate that there are marginal differences in moisture content, moisture regain, EPI and PPI. But effects on fabric strength loss, color fading, stiffness, shrinkage and GSM are observed with increases of time up to $60 \mathrm{~min}$. It can also be seen from Table 3 that water absorption increased after washing and the rate of water absorption varies between washed and unwashed denim and it increased rapidly up to certain time (40 $\mathrm{min}$ ), then increased slowly (55 min) but a higher duration $(60 \mathrm{~min})$ does not cause any further increase in water absorption. As mentioned previously (Kwon \& Sarmadi 1995), the water absorption increased after laundering and the rate of water absorption varies upon fabric status (finished/unfinished) and it increased up to certain level of washing then water absorption decreased, which is corelated to our obtained results of water absorption in denim garment washing. So considering fabric properties $40 \mathrm{~min}$ washing time is optimum for denim washing with cellulase.

\section{Scanning electron micrograph}

The morphological of the denim garments was examined by scanning electron microscopy (SEM) on the untreated and treated samples. The washing treatment is affected by $2 \%$ cellulase for $40 \mathrm{~min}$ at $55^{\circ} \mathrm{C}$. Figure 1 (a) shows SEM images $(15.0 \mathrm{kV} \times 35$, magnification 525) of untreated cotton denim garment and Figure 1(b) shows SEM images
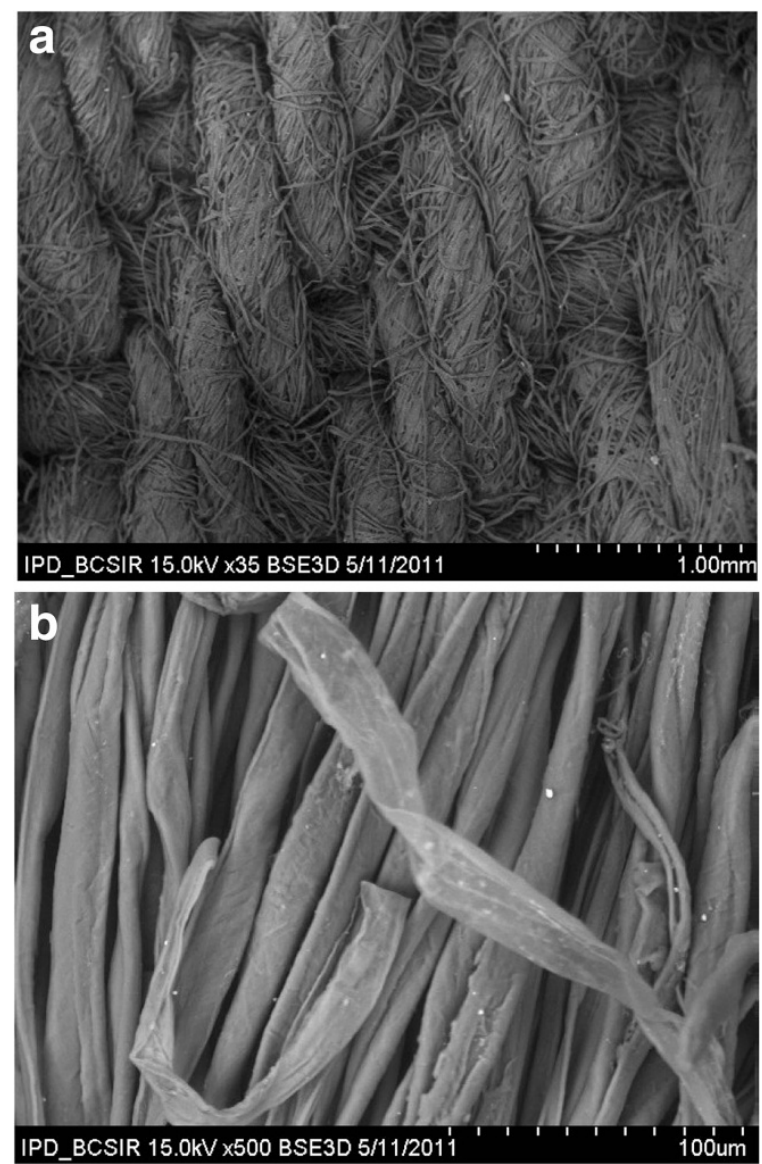

Figure 1 Scanning electron micrograph of denim garment: (a) untreated denim garment and (b) untreated denim garment (magnified). 
(15.0 kV $\times 500$, magnification 7500) of untreated cotton denim garment (magnified). The Figure 1 shows parallel ridges and no fibrils (projecting fibers) and ruptures visible in the images, because yarns are coated with size materials and projecting fibers are not visible on surface.

Figure 2(a) shows SEM images $(15.0 \mathrm{kV} \times 35$, magnification 525$)$ of enzyme treated cotton denim garment and Figure 2(b) shows SEM images $(15.0 \mathrm{kV} \times 500$, magnification 7500) of enzyme treated cotton denim garment (magnified). For Figure 2, the washing condition is followed by $2 \%$ cellulase for $40 \mathrm{~min}$ at $\mathrm{pH} 5.5$ and $55^{\circ} \mathrm{C}$ in the fiber-liquor ratio of 1:530. Figure 2 shows loosened, disoriented and wrinkled surfaces due to fiber degradation by hydrolysis and abrasion were due to mechanical friction by the washing machine during processing. As mentioned previously (Betrabet et al. 1980; Li \& Hardin 1998), the enzyme attacks the cellulose of cotton progressively, the primary wall being the first target. As observed in Figure 2, there are more cracks on the surface of fibers. This is caused by cellulase washing of cotton denim garments.

\section{Conclusions}

The use of cellulase enzyme in denim washing is very effective. The tensile strength, stiffness and color shade decrease after cellulase treatment. Hydrolysis of the cotton
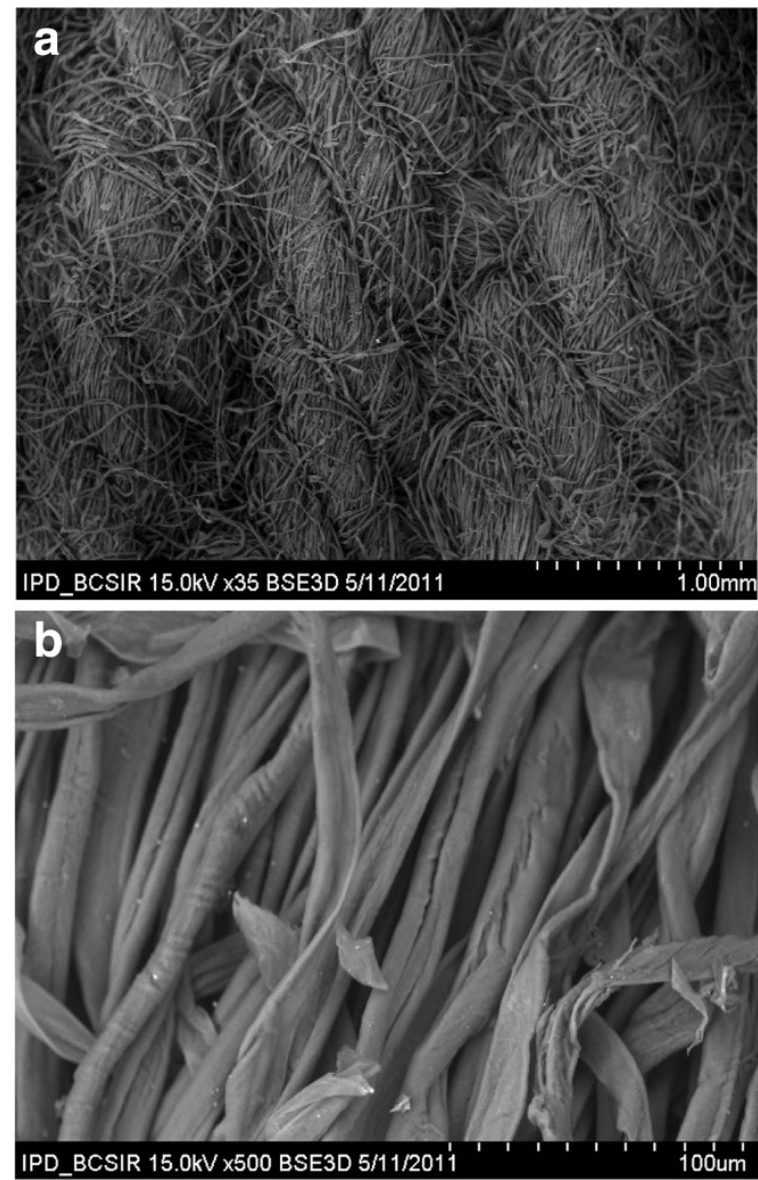

Figure 2 Scanning electron micrograph of denim garment: (a) after enzyme treatment and (b) after enzyme treatment (magnified). 
denim garments caused enhanced color fading, softness, water absorption and elongation; meanwhile, tensile strength is decreased. The rate of denim softness, water absorption and moisture regain increase due to catalytic hydrolysis by the cellulase (fibers are loosened by the enzyme). The fabric GSM obtained with cellulase washing is a little higher than those of pre-washing due to more fabric shrinkage in the warp direction, although Koo et al. (1994) found GSM decreased for mercerized cotton than unmercerized cotton fabrics. Examination of the cellulase treated fibers by SEM shows more cracked cellulose on the surface; as a result, fibers are loosened and resulting rougher surface on those denim fabrics. It is further noted that pre-washed denim samples were stiff and harder than cellulase treated cotton denim garments.

Competing interests

Both authors declare that they have no competing interest in relation to this study.

\section{Authors' contributions}

IHM and MRK contributed to conception and design of the study. MRK carried out experiments on analysis and characterization. Both authors read and approved the final manuscript.

\section{Acknowledgements}

One of the authors was supported by the NSICT fellowship of the Ministry of Science and Information \& Communication Technology of the Government of Bangladesh. We would like to thank to Dr. Jacqualyn Eales of Bangor University, UK for checking the language and technical points.

Received: 18 August 2014 Accepted: 28 October 2014

Published online: 12 December 2014

\section{References}

AATCC test method 61. (2010). Colorfastness to laundering, home and commercial: accelerated. In American Association of Textile Chemists and Colorists. N.C., USA: Research Triangle Park.

AATCC test method 96. (2009). Dimensional changes in commercial laundering of woven and knitted fabrics except wool. In American Association of Textile Chemists and Colorists. N.C., USA: Research Triangle Park.

ASTM D 1776. (2008). Standard practice for conditioning textiles for testing. In American Society for Testing and Materials, Annual Book of ASTM Standards, Vol.07.01. West Conshohocken, PA, USA: ASTM International.

ASTM D 1909. (2004). Table of commercial moisture regains for textile fibers. In American Society for Testing and Materials, Annual Book of ASTM Standards, Vol.07.01. West Conshohocken, PA, USA: ASTM International.

ASTM D 3776. (1996). Standard test methods for mass per unit area (weight) of woven fabric. In American Society for Testing and Materials, Annual book of ASTM Standards, Vol. 07.02. West Conshohocken, PA, USA: ASTM International.

ASTM D 5034. (2009). Standard test method for breaking force and elongation of textile fabrics (Grab test). In American Society for Testing and Materials, Annual book of ASTM Standards, Vol. 07.01. West Conshohocken, PA, USA: ASTM International.

Betrabet, SM, Paralikar, KM, \& Patil, NB. (1980). Effect of cellulase on the morphology and fine structure of cellulose substrates. Cellulose Chemistry and Technology, 14, 811-820.

BS 3356. (1990). Method for determination of bending length and flexural rigidity of fabrics. Chiswick High Road, London: BSI Publisher.

BS 3449. (1990). Testing the resistance of fabrics to water absorption (static immersion test). Chiswick High Road, London: BSI Publisher.

Buchert, J, \& Heikinheimo, L. (1998). New cellulase processes for the textile industry. EU-Project Report. Carbohydr Eur, $22,32-34$.

Butler, SM, \& Francis, S. (1997). The Effects of Environmental Attitudes on Apparel Purchasing Behavior. Clothing and Textile Research Journal, 15, 76-85.

Cookson, PG. (1992). Relationships between hygral expansion, relaxation shrinkage, and extensibility in woven wool fabrics. Textile Research Journal, 62, 44.

Duran, N, \& Mercela, N. (2000). Enzyme applications in the textile industry. Review Progress in Coloration, 30(1), 41-44.

Eckman, M. (1997). Attractiveness of Men's Suits: The Effect of Aesthetic Attributes and Consumer Characteristics. Clothing and Textile Research Journal, 15, 193-202.

Gam, HJ, \& Banning, JJ. (2011). Addressing Sustainable Apparel Design Challenges With Problem-Based Learning. Clothing and Textiles Research Journal, 29, 202-215.

Grieve, M, Biermann, T, \& Schaub, K. (2006). The use of indigo derivatives to dye denim material. Science \& Justice, $46,15-24$.

Grieve, M, \& Biermann, T. (1997). The population of colored textile fiber on outdoor surfaces. Science \& Justice, 37, 231-239.

Heikinheimo, L, Buchert, J, Miettinen-oinonen, A, \& Suominen, P. (2000). Treating denim fabrics with trichoderma reesei cellulases. Textile Research Journal, 70(11), 969-973.

Heikinheimo, L, Cavaco-Paulo, A, Nousiainen, P, Siika-aho, M, \& Buchert, J. (1998). Treatment of cotton fabrics with purified trichoderma reesei cellulases. Journal of the Society of Dyers and Colourists, 114(7-8), 216-220.

Islam, MT. (2010). Garments washing \& dyeing (1st ed., pp. 220-222). Dhaka: Ananto publications. 
Kang, I, Yang, C, Wei, W, \& Lickfield, GC. (1998). Mechanical strength of durable press finished cotton fabrics Part 1: Effects of acid degradation and cross linking of cellulose by polycarboxylic acids. Textile Research Journal, 68, 856-870.

Kashem, MA. (2008). Garments Merchandising (1st ed., pp. 69-71). Dhaka: Lucky-one traders.

Kawamura, H, \& Wakida, T. (1989). Application of enzymes in textile finishing. Bull Apparel Sci Res Cent, Kyoto Institute of Technology, Japan. 8, 99.

Kleman-Leyer, KM, Siika-aho, M, Teeri, T, \& Kirt, TK. (1996). The cellulases endoglucanase I and cellobiohydrolase II of trichoderma reesei act synergistically to solubilize native cotton cellulose but not to decrease its molecular size. Applied and Environmental Microbiology, 62(8), 2883-2887.

Kochavi, D, Videbaek, T, \& Cadroni, D. (1990). Optimizing processing conditions in enzymatic stone washing. American Dyestuff Reporter, 9, 24-28.

Koo, H, Ueda, M, Wakida, T, Yoshimura, Y, \& Igarashi, T. (1994). Cellulase treatment of cotton fabrics. Textile Research Journal, 64(2), 70-74.

Kwon, YA, \& Sarmadi, AM. (1995). Wettability of Nonwoven Fabrics: Effect of Laundering on Water Absorption. Clothing and Textiles Research J, 13, 17-29.

Li, Y, \& Hardin, I. (1998). Treating cotton with cellulases and pectinases: Effects on cuticle and fiber properties. Textile Research Journal, 68(9), 671-679.

Morries, CE, \& Harper, RJ. (1994). Comprehensive view on garment dyeing and finishing. American Dyestuff Reporter, $83,132-136$.

Prabaharan, M, Nayar, RC, \& Rao, JV. (2000). Process Optimization in Peracetic Acid Bleaching of Cotton. Textile Research Journal, 70(8), 657-661.

Razzaque, MA. (2004). Garment \& Textile Merchandising (1st ed., pp. 223-226). Dhaka: Popular publications.

Tyndall, M. (1990). Upgrading garment washing techniques. American Dyestuff Reporter, 5, 22-30.

Tyndall, RM. (1992). Improving the softness and surface appearance of cotton fabrics and garments by treatment with cellulase enzymes. Textile Chemist and Colourist, 24, 23-26.

Walker, LP, \& Wilson, DB. (1991). Enzymatic hydrolysis of cellulose: An overview. Bioresource Technology, 36, 3-14.

Wood, TM. (1992). Fungal Cellulases. Biochemical Society Transactions, 20, 46-52.

doi:10.1186/s40691-014-0019-0

Cite this article as: Mondal and Khan: Characterization and process optimization of indigo dyed cotton denim garments by enzymatic wash. Fashion and Textiles 2014 1:19.

\section{Submit your manuscript to a SpringerOpen ${ }^{\circ}$ journal and benefit from:}

- Convenient online submission

Rigorous peer review

- Immediate publication on acceptance

- Open access: articles freely available online

- High visibility within the field

- Retaining the copyright to your article

Submit your next manuscript at $\boldsymbol{~ s p r i n g e r o p e n . c o m ~}$ 